6 [5] 181-191 (1965).

21) D. Turnbul and M.H. Cohen, "Crystallization kinetics and glass formation" in J.D. Mackenzie Ed. "Modern aspects of the vitreous state-I" Butter- worths (1960) pp.38-62.

22) S.D. Stookey, Glastech. Ber. 32 K, VI (1959)

(2/22/1968 受付)

\title{
40. Wavelength Dependence of Stress in Glass Caused by Ultra-Violet Light
}

\author{
Stress in Glass Caused by Ultra-Violet Irradiation (Part 12)
}

By

Kazuo ŌOKA and Tōru KISHII

(Tokyo Shibaura Electric Co., Kawasaki, Japan)

Stress is built up in borate and borosilicate glasses by ultra-violet light and a series of experiments were carried out by the authors to clarify the mechanisms of the phenomenon ${ }^{1)}$.

Experimental results indicated that the stress was a result of contraction of glass at a irradiated thin surface layer about $0.2 \mathrm{~mm}$ thick for commercial borosilicate glasses, and the value of the stress was considerably influenced by thermal history of glass or by impurity or a small amount of additional components in glass.

For the start of the process induced by light (or other electromagnetic waves), photon must be absorbed in material and the energy given or transfered to the reacting system must exceed a threshold value. The threshold value is considered to be a key to elucidate the mechanisms of the process.

The threshold photon energy for stress build-up was examined. Compositions of sample glasses are shown in Table 1. Transmission curves of thin plates of the glasses are given in Fig. 1 . Prisms $(15 \times 10 \times 5 \mathrm{~mm})$ of the glasses were exposed to ultra-violet light. The source of ultra-violet light was a $400 \mathrm{~W}$ mercury discharge lamp made of fuzed silica glass $(19 \phi \times 150 \mathrm{~mm})$. Various kinds of glass filters were inserted between the lamp and sample prisms. The distances between the lamp and the filters and between the filters and the prisms were both $15 \mathrm{~mm}$. Prisms were examined photoelasti-

Table 1. Composition of the glasses (wt \%)

\begin{tabular}{lccccccccc}
\hline \multicolumn{1}{c}{$\mathrm{SiO}_{2}$} & $\mathrm{Al}_{2} \mathrm{O}_{3}$ & $\mathrm{~B}_{2} \mathrm{O}_{3}$ & $\mathrm{Na}_{2} \mathrm{O}$ & $\mathrm{K}_{2} \mathrm{O}$ & $\mathrm{Fe}_{2} \mathrm{O}_{3}$ & $\mathrm{As}_{2} \mathrm{O}_{3}$ & $\mathrm{Cl}$ & $\mathrm{Li}_{2} \mathrm{O}$ & $\mathrm{BaO}$ \\
\hline $\begin{array}{l}\text { Terex } \\
\text { Kovar }\end{array}$ & 2.44 & 12.65 & 3.80 & 0.41 & 0.065 & 0.20 & & \\
$\begin{array}{l}\text { sealing } \\
\text { glass }\end{array}$ & 75.4 & 7.5 & 18.0 & 1.9 & 3.0 & 0.2 & 1.0 & 3.0 \\
Pyrex* 80.55 & 2.25 & 12.94 & 4.20 & 0.01 & 0.026 & 0.025 & 0.043 & \\
\hline
\end{tabular}

* Corning Glass Works cally after irradiation for $1000 \mathrm{hrs}$.

Preliminary experiment indicated that filters which completely absorbed light in the wavelength

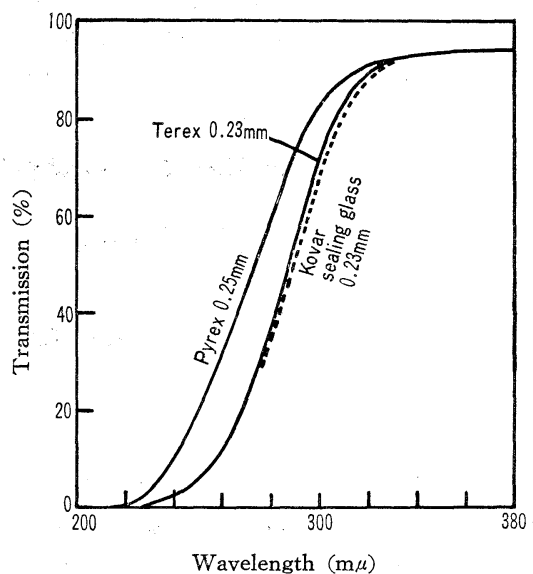

Fig. 1. Transmission curves of thin plates of the glasses

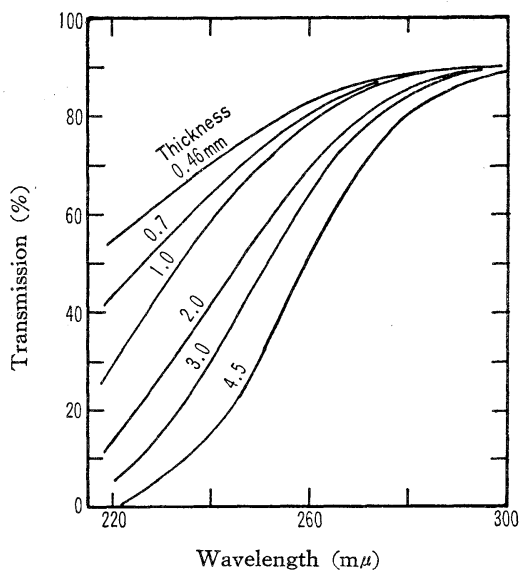

Fig. 2. Transmission curves of UV-25 filters with various thicknesses 
Thickness of filters (mm)

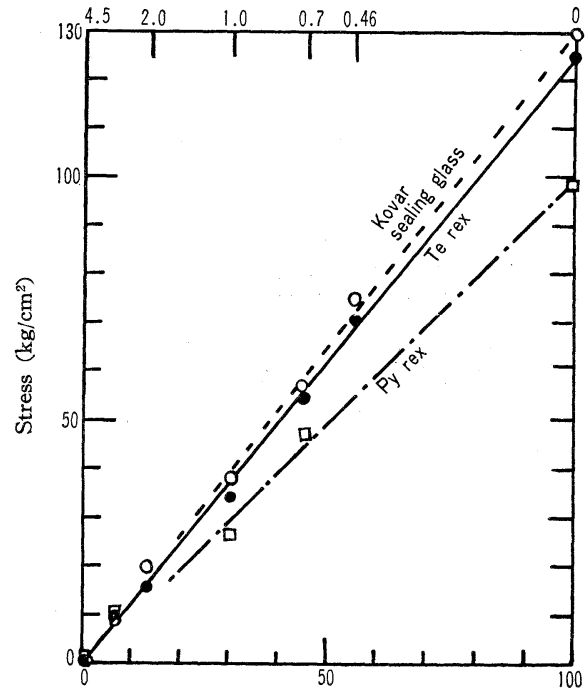

Transmission of filters at $220 \mathrm{~m} \mu$ (\%)

Fig. 3. Relation between stress and transmission of filters (at $220 \mathrm{~m} /$ )

region less than $270 \mathrm{~m} \mu$ prevented the stress from being built up. So, Toshiba UV-25 filters with various thicknesses were used. Transmission curves of the filters are given in Fig. 2.

The values of the stresses are plotted in Fig. 3 against the transmission at $220 \mathrm{~m} \mu$ of the filters used. Apparently, proportionality between these quantities is good. It is, therefore, concluded that the stress in glass is caused by ultra-violet light with photon energy of $5.7 \mathrm{eV}(220 \mathrm{~m} \mu)$ or more. Fig. 1 indicates that the light in the wavelength region less than $220 \mathrm{~m} \mu$ is completely absorbed in thin layers of the glasses. The above conclusion is compatible with the previous discussions by the authors that the process might be initiated by either excitation (the threshold energy is about $4.5 \mathrm{eV}$ ) or ionization (the threshold energy is about $5.5 \mathrm{eV}$ ) of non-bridging oxygen ions in glasses. Doping of some kinds of oxide might shift the threshold to longer wavelength region and sensitize the stress build-up ${ }^{1 a)}$. The effect is now under investigation.

\section{References}

1) K. Ōoka and T. Kishii, for example, a. J. Ceram. Assoc. Japan 72 [11-1] 193 (1964); b. ibid. 76 [1] 6 (1968); c. Preprint of The Annual Meeting of The Intern. Congress on Glass p. 259, Sept. (1966) Tokyo.

[Received March 5, 1968]

\title{
紫外線により発生するガラス中の応力の波長依存性
}

\author{
紫外線照射によるガラス中の応力発生（第 12 報）
}

\section{大岡一夫・岸 井 貫 \\ （東京芝浦電気株式会社）}

紫外線透過率がたがいに異なる数種のガラスフィルタ を光源との間に入れて，3種の商用嗍珪酸ガラスを紫外 線で 1,000 時間照射した. 照射された面に発生した応力 は，使用したフィルタの $220 \mathrm{~m} \mu$ における透過率とほぼ 比例した。 それゆえ， $220 \mathrm{~m} \mu$ あるいはそれ以下の短波 長の光が応力を発生させると考えられる。この波長域の 光は, 厚さ $0.2 \mathrm{~mm}$ のガラスでほとんど吸収される. それ沛え，光子エネルギーを吸収することと，そのエネ ルギーがあるしきい值を超えることとが反応開始に必要
であるという, 光化学の基本原則はこの場合にも満たさ れている.また, $220 \mathrm{~m} \mu$ は $5.7 \mathrm{eV}$ の光子エネルギー に相当するので, 上記の実験結果は, 応力発生過程は非 架橋酸素イオンの 励起（必要な最低エネルギーは 4.5 $\mathrm{eV}$ ) またはイオン化（必要な最低エネルギーは $5.5 \mathrm{eV}$ ) から始まるといら, 著者らの提出した仮説とも適合して いる.

(3/5/1968 受付) 